\title{
Increasing Underrepresented Scientists in Cancer Research: The UCSD CURE Program
}

\author{
Lawrence Alfred • Paula R. Beerman • Zunera Tahir • \\ Sheila F. LaHousse • Percy Russell • \\ Georgia Robins Sadler
}

Published online: 11 May 2010

(C) The Author(s) 2010. This article is published with open access at Springerlink.com

\begin{abstract}
The Moores UCSD Cancer Center's Continuing Umbrella of Research Experiences program aims to increase the number of underrepresented students pursuing careers in cancer research, cancer care, and health disparities research. Participants receive 8 weeks of laboratory and classroom training during the summer followed by participation in research mentors' laboratories. Of the 82 CURE students accrued (2002 and 2008), 91\% persisted in science after 1 year. Of the 63 students eligible to graduate in 2009,7 had dropped out of college; 56 graduated. Of the graduates, $98 \%$ were science majors and $61 \%$ (34) had already matriculated to graduate or health professional schools for cancer research and clinical care careers.
\end{abstract}

Presented at American Association for Cancer Education Meeting, Houston, Texas, October 2009

This research was funded by NIH grants: P30CA23100; U56CA92079/U56CA92081; U54CA132379/U54CA132384; 5P60MD000220; 5R25CA65745; and U01CA114640. Its contents are solely the responsibility of the authors and do not necessarily represent the official views of the National Institutes of Health.

L. Alfred · P. R. Beerman · Z. Tahir · S. F. LaHousse • P. Russell •

G. R. Sadler $(\bowtie)$

Moores UCSD Cancer Center, 0850,

3855 Health Sciences Drive,

La Jolla, CA 92093-0850, USA

e-mail: gsadler@ucsd.edu

P. Russell

UCSD Department of Chemistry,

9500 Gilman Drive,

La Jolla, CA 92093, USA

G. R. Sadler

Department of Surgery, UCSD School of Medicine,

9500 Gilman Drive,

La Jolla, CA 92093, USA
MeSH Minority scientists · Training · Cancer careers · Mentoring · Undergraduates · Underrepresented students

\section{Introduction}

The disproportionate burden of cancer and other negative health disparities within minority communities is well documented [1-5]. Haynes and Smedley [6] discussed many contributing factors: behavioral risk factors; cultural beliefs; socioeconomic factors [7, 8]; genetics [9]; and reduced healthcare access.

The National Institutes of Health's (NIH) Minority Health Initiative (1992) was created to identify strategies to ameliorate these disparities. Minority clinicians' underrepresentation contributes to health disparities by reducing minority community members' access to culturally competent health information and care $[4,5]$. This underrepresentation also narrows the scientific community's insights regarding ways these disparities might be resolved.

To address these disparities, NIH sponsors training programs to increase underrepresented (UR) students' interest in becoming scientists and clinicians and success with sciences majors [10]. The NIH Office of Research on Minority Health monitors these training programs' outcomes. A recent assessment by the National Academies [11] noted the need for continued expansion of the pipeline of UR scientists and clinicians and urged more rigorous evaluation of these training programs.

Recent reports found that $19 \%$ of African Americans and $23 \%$ of Hispanic Americans enter college with the same level of interest in the sciences as that of Asian Americans (26\%) and White Americans (18\%) [12, 13]. However, a disproportionate number of UR students leave the sciences due to feelings of cultural and academic isolation and a 
lack of support programs that foster achievement of their academic potentials. The National Science Foundation reported significantly lower levels of persistence and college degrees in the sciences among African American and Hispanic American college students than their peers [14]. Compared to White and Asian American students, African American, Hispanic American, and Native American students together receive only $12 \%$ of bachelor's degrees, $7 \%$ of master's degrees, and $4 \%$ of science doctorates.

The National Cancer Institute offered its NCI-designated cancer centers supplemental funding for Continuing Umbrella of Research Experience (CURE) programs designed to reduce this underrepresentation [15]. Through the CURE program, NCI-designated cancer centers create training programs to attract UR students to careers in cancer care and science. This paper describes the Moores UCSD Cancer Center's CURE program's success with students accrued from 2002 to 2008 .

\section{Materials and Methods}

\section{Eligibility Requirements and Consenting Process}

Students had to be at least 18 years old and interested in pursuing a science major. Preference was given to students who were incoming UCSD freshmen, sophomores, or community college transfer students with an overall GPA of 3.0 or higher. They also had to meet at least one of the following characteristics: (1) UR community member; (2) low income; or (3) neither parent holds a degree from a 4-year United States college. Applicants completed sociodemographic questionnaires, provided two letters of references from science teachers/professors. Participants signed an IRB-approved consent document permitting program leaders to use student-related data to evaluate the program and disseminate findings.

\section{Recruitment Strategies}

The program leaders developed a referral network of high school teachers, university recruitment officers, and community college professors. Students were recruited using IRB-approved brochures that were delivered via: inperson communication; Internet networking; the Cancer Center's website; and science classrooms and student organizations.

Structure of the Intervention

Students participate in an intensive, 8-week summer research training program of hands-on training in biochem- istry/cell biology. This program also includes seminars and workshops that help students succeed academically and professionally, including: training in behavioral science research; IRB/HIPAA certification; training in the conduct of in-depth literature reviews/synthesis; preparation of poster/podium/PowerPoint presentations; training in personal, academic, and career goal setting; and time management skills using the SMART model (Specific, Measurable, Achievable, Realistic, and Timely) [16].

Following the summer training program, students can opt to be paired with NIH-funded faculty mentors to gain additional research experience, expand their exposure to cancer careers, and increase their competitiveness for admission to graduate and health professional schools. CURE program leaders continue mentoring students through on-going meetings and help faculty mentors to prepare diversity supplements and justify grant-funded positions to assure stable funding for their CURE students.

\section{Outcome Measures}

Table 1 shows the process and outcome measures used to evaluate this CURE program's success, including students' persistence in science after 1 year, retention in science to graduation, and matriculation into graduate level training programs in the sciences. Additional interim evaluative data are drawn from students' socio-demographic surveys, standardized laboratory safety exams, laboratory skills exams, grades, classes, declared majors/minors, honors, publications/presentations, admission to enrichment programs, extracurricular activities, research achievements, and graduate school prospects.

\section{Description of the Sample}

Of the 82 students, $72 \%$ were female and $28 \%$ were male. Their ages ranged from 18 to 30 , with a mean age of 21 $(\mathrm{SD}=2.6)$. Of the sample, $100 \%$ was eligible under the designation of economically disadvantaged. Of the 82 students in this sample, $78 \%$ of their fathers and $85 \%$ of mothers did not complete a college education in the USA. The ethnic breakdown is shown in Table 2. Of this group, $59 \%$ entered the CURE program as freshmen or sophomores, $29 \%$ as juniors/seniors, and $12 \%$ as community college transfers.

\section{Data Analysis}

Data were analyzed using the Statistical Package for the Social Sciences (SPSS-v14). Descriptive and frequency statistics were calculated to measure the program's effectiveness. 
Table 1 Process and outcome data used to evaluate the UCSD CURE program

\begin{tabular}{|c|c|c|c|}
\hline $\begin{array}{l}\text { Socio-demographic and } \\
\text { psychosocial }\end{array}$ & CURE program participation & $\begin{array}{l}\text { Graduation and research } \\
\text { achievements }\end{array}$ & Post-baccalaureate outcomes \\
\hline $\begin{array}{l}\text { - Ethnicity, gender, } \\
\text { and primary language } \\
\text { - College major }\end{array}$ & $\begin{array}{l}\text { - Academic research } \\
\text { workshops } \\
\text { - Scientific writing course }\end{array}$ & $\begin{array}{l}\text { - Graduation in science major } \\
\text { - Research laboratory experience } \\
\text { in content specialization area }\end{array}$ & $\begin{array}{l}\text { - Number enrolled in } \\
\text { post-baccalaureate programs } \\
\text { (Masters, PhD, MD, DO, } \\
\text { DDS, Pharm D) }\end{array}$ \\
\hline - Entry year into program & - Seminars & $\begin{array}{l}\text { - Authorship on scientific } \\
\text { peer-reviewed publications }\end{array}$ & $\begin{array}{l}\text { - Number with pre-doctoral } \\
\text { and doctoral fellowships }\end{array}$ \\
\hline - Entry and on-going GPA & - Ethics course & $\begin{array}{l}\text { - Presenting authors at } \\
\text { peer-reviewed scientific } \\
\text { conferences }\end{array}$ & $\begin{array}{l}\text { - Number graduated } \\
\text { from post-baccalaureate } \\
\text { programs }\end{array}$ \\
\hline $\begin{array}{l}\text { - Parents' academic preparation } \\
\text { and support } \\
\text { - Psychosocial (e.g., } \\
\text { personal effectiveness, } \\
\text { academic motivation) }\end{array}$ & $\begin{array}{l}\text { - Preparation course for } \\
\text { graduate school } \\
\text { applications } \\
\text { (e.g., GRE, MCAT, } \\
\text { statement of purpose, } \\
\text { eliciting letters of support) }\end{array}$ & $\begin{array}{l}\text { Honors, awards, scholarships, } \\
\text { fellowships, traineeships, } \\
\text { exchanges }\end{array}$ & $\begin{array}{l}\text { - Number working in health } \\
\text { or research careers } \\
\text { - Number working in cancer } \\
\text { related careers }\end{array}$ \\
\hline - Persistence in the sciences & $\begin{array}{l}\text { - International or domestic } \\
\text { academic exchange }\end{array}$ & & $\begin{array}{l}\text { Honors, awards, scholarships, } \\
\text { fellowships, traineeships, } \\
\text { exchanges }\end{array}$ \\
\hline
\end{tabular}

\section{Results}

The 82 CURE students all professed a strong interest in pursuing careers in health and science fields at baseline. "Persistence" in the sciences is defined by the University of California as incoming students who continue as science majors after the first year at university [17]. The CURE students showed a persistence rate of 93\% (76) after 1 year compared to UCSD's persistence rate of $94 \%$ for all science majors. The remaining six students dropped out of college during their first year.

By summer 2009, 63 of the 82 participants would have been eligible to graduate. Of those 63, a total of seven students had dropped out of college and $56(89 \%)$ had graduated (Table 2). Of 56 graduates, 55 (98\%) graduated as science majors, an outcome that compares favorably to UCSD's $72 \%$ retention in the sciences through to graduation
[Student Research and Information, Student Affairs, University of California, San Diego, (personal communication, Dr. William Armstrong, Director), 2008. 15 Jan. 2010]. Since UCSD does not publish the actual numbers for these categories, it was not possible to determine whether this difference was statistically significant.

The ultimate seminal outcome for this program was whether CURE program graduates would pursue postbaccalaureate programs leading to research and clinical careers in cancer. To date, $34(61 \%)$ of those 56 graduates have already matriculated into programs leading to master's or doctoral of science degrees in pharmacy, medicine, basic sciences, clinical psychology, advanced practice nursing, or other disciplines related to careers in cancer research and clinical care (an additional student completed graduate training in the arts). Of the remaining 21 students, 20 (36\%) opted to work

Table 2 CURE undergraduate and post-baccalaureate status by ethnicity, 2002-2008

\begin{tabular}{|c|c|c|c|c|c|c|c|}
\hline \multirow[t]{2}{*}{ Ethnicity $(n)$} & \multirow{2}{*}{$\begin{array}{l}\text { Number still } \\
\text { in college }(n)\end{array}$} & \multirow{2}{*}{$\begin{array}{l}\text { Dropped from } \\
\text { program }(n)\end{array}$} & \multirow{2}{*}{$\begin{array}{l}\text { Graduated BA/ } \\
\text { BS degree }(n)\end{array}$} & \multicolumn{4}{|c|}{ Post-BS/BA follow-up $(n)$} \\
\hline & & & & $\begin{array}{l}\text { Percent in } \\
\text { graduate school }\end{array}$ & $\begin{array}{l}\text { Percent in } \\
\text { medical school }\end{array}$ & $\begin{array}{l}\text { Working without } \\
\text { graduate training }\end{array}$ & $\begin{array}{l}\text { Lost to } \\
\text { follow-up }\end{array}$ \\
\hline African American 17\% (14) & 3 & 3 & 8 & $63 \%(5)$ & $25 \%(2)$ & $13 \%(1)$ & $0 \%(0)$ \\
\hline Hispanic American 43\% (36) & 11 & 1 & 24 & $46 \%(11)$ & $4 \%(1)$ & $46 \%(11)$ & $4 \%(1)$ \\
\hline Asians 33\% (27) & 3 & 1 & 23 & $39 \%(9)$ & $30 \%(7)$ & $30 \%(7)$ & $0 \%(0)$ \\
\hline $\begin{array}{l}\text { Native American } \\
\text { and Other } 6 \%(5)\end{array}$ & 2 & 2 & 1 & $0 \%(0)$ & $0 \%(0)$ & $100 \%(1)$ & $0 \%(0)$ \\
\hline Totals $99 \%(82)$ & $23 \%(19)$ & $9 \%(7)$ & $68 \%(56)$ & $45 \%(25)$ & $18 \%(10)$ & $36 \%(20)$ & $2 \%(1)$ \\
\hline
\end{tabular}


in scientific research or teach science. Among the key reasons reported for not immediately attending graduate school were: needing to pay off student loans; needing to provide financial assistance to their family; or wanting to gain additional laboratory research experience or coursework to become more competitive graduate school applicants. One graduate remains lost to follow-up.

\section{Discussion}

The CURE students were selected from the UCSD's undergraduates, a cohort with highly documented academic and professional promise. The $93 \%$ persistence in the sciences after 1 year for CURE science majors was comparable to UCSD's $94 \%$ for all science majors. This is notable because CURE students generally come from socioeconomically challenged backgrounds and less affluent high schools than their majority peers, putting them at a distinct disadvantage to succeed. Transferring from a community college creates additional challenges to success. An equally good outcome was found for persistence in the sciences through graduation $(98 \%$ versus $72 \%$ ). While there are no comparable graduation and post-baccalaureate training matriculation data available for UCSD students in general, the CURE students' graduation and matriculation into graduate school rates were very high. The 10-year study of Matsui et al. [18] of UC Berkeley's Biology Scholar's Program (BSP) showed a similar positive program impact for BSP compared to non-BSP control groups.

Several factors beyond the content of the training program appeared to contribute to the CURE program's success. First, the constant monitoring of CURE students' progress enabled the program leaders to identify quickly students who were not staying on track academically and with sufficient time to intervene with counseling and referrals for tutoring. A second was helping to relieve students' financial pressures; a third was to provide work where they gained laboratory experiences that enhanced their academic performance and graduate school competitiveness. Fourth was the provision of strong science role models and mentors, and fifth was the program leaders' and faculty mentors' championing activities, including alerting students to additional enrichment opportunities, including them as peers on manuscripts and abstracts/presentations and personally endorsing their efforts to succeed with supportive letters and other communications.

In contrast, program attrition occurred because students dropped out of college entirely as a result of sociodemographic impediments to success, circumstances that this program was not designed to address. This finding suggests that future incoming students should have a oneon-one session with a program leader early in the training program to identify these types of impediments to success, so that at-risk students can be offered additional University support services.

While the National Center on Minority Health and Health Disparities [10] and the National Research Council [11] have urged universities to conduct evaluations of NIHfunded intervention programs to expand the pipeline of students from underrepresented communities, measuring the true impact of such programs is wrought with challenges. For example, the current study's sample was small, the students were all drawn from one university, and the study had no control group with which comparisons could be made. The limited funding for such programs hampers rigorous scientific evaluation. This is further complicated by the ethical dilemma of how to construct a true control group when there are alternate enrichment opportunities for control group participants.

Mentoring has been shown to be one of the most powerful tools in motivating UR students to stay in science, graduate from college, matriculate into graduate school, and pursue academic careers [19-22]. Mentoring includes academic and career advising, dissemination of information on available resources, assistance in navigating the academic system, promotion of students' selfefficacy [22], and guidance in coping with their sociodemographic challenges to success. The experiences gained from UCSD's CURE program lend support to the conclusion that mentoring is at the heart of successful programs that seek to advance UR students' academic and professional achievements.

\section{Conclusion}

UCSD's CURE program data suggest that the success of its students was due to the recruitment of students who had the potential to thrive in the sciences and the support and involvement of dedicated faculty members who nurtured and mentored these students' academic careers throughout college and beyond.

Acknowledgements The authors express their appreciation for the contributions by Anita Williams and Ami Abbott who managed the biochemistry laboratory in the Summer Science Enrichment component of the CURE Program, as well as undergraduates Manpreet Mumman, April Newell, Abraham Nguyen, Anthony Orona, Joseph Rubio, and Kathleen Sered.

Open Access This article is distributed under the terms of the Creative Commons Attribution Noncommercial License which permits any noncommercial use, distribution, and reproduction in any medium, provided the original author(s) and source are credited. 


\section{References}

1. Cancer Health Disparities: Fact Sheet. National Cancer Institute. 2007

2. Thomas SB, Fine MJ, Ibrahim SA (2004) Health disparities: the importance of culture and health communication. Am J Public Health 94(12):2050

3. Betancourt JR, Green AR, Carrillo JE, Ananeh-Firempong O 2nd (2003) Defining cultural competence: a practical framework for addressing racial/ethnic disparities in health and health care. Public Health Rep 118(4):293-302

4. Betancourt JR (2006) Eliminating racial and ethnic disparities in health care: what is the role of academic medicine? Acad Med 81 (9):788-792

5. Kamangar F, Dores GM, Anderson WF (2006) Patterns of cancer incidence, mortality, and prevalence across five continents: defining priorities to reduce cancer disparities in different geographic regions of the world. J Clin Oncol 24 (14):2137-2150

6. Haynes MA, Smedley BD, Institute of Medicine (U.S.). Committee on Cancer Research among Minorities and the Medically Underserved (1999) The unequal burden of cancer: an assessment of NIH research and programs for ethnic minorities and the medically underserved. National Academy Press, Washington, D.C

7. Freeman HP (2006) Patient navigation: a community based strategy to reduce cancer disparities. J Urban Health 83(2):139-141

8. Nash D, Azeez S, Vlahov D, Schori M (2006) Evaluation of an intervention to increase screening colonoscopy in an urban public hospital setting. J Urban Health 83(2):231-243

9. Chow JY, Dong H, Quach KT, Van Nguyen PN, Chen K, Carethers JM (2008) TGF-beta mediates PTEN suppression and cell motility through calcium-dependent PKC-alpha activation in pancreatic cancer cells. Am J Physiol Gastrointest Liver Physiol 294(4):G899-G905
10. The National Center on Minority Health and Health Disparities (2008) The NIH Almanac. http://grants.nih.gov/grants/guide/ pa-files/PA-05-015.html

11. Assessment of NIH Minority Research and Training Programs (2005). http://www.nap.edu/openbook.php?record_id=11329* page $=159$

12. Anderson EL, Kim D, American Council on Education (2006) Unfinished Agenda Initiative (Project). Increasing the success of minority students in science and technology. American Council on Education, Washington, D.C

13. Summers MF, Hrabowski FA 3rd (2006) Preparing minority scientists and engineers. Science 311(5769):1870-1871

14. Feigener M (2009) Science and engineering degrees, by race/ ethnicity: 1997-2006. National Science Foundation

15. Research supplements to promote diversity in health-related research (2001) http:grants.nih.gov/grants/guide/pa-files/PA-08-190.html

16. Specific Measurable, Achievable, Realistic and Timely (2009) http:www.leads.wayne.edu/phase1/smart.php

17. UCSD Student Research and Information, Student Affairs. 2007-2008

18. Matsui JLR, Lui R, Kane CM (2003) Evaluating a science diversity program at UC Berkeley: more questions than answers. Cell Biol Educ 2:117-121

19. Betz NE (1997) Increasing research involvement and interests among graduate students in counseling psychology. Couns Psychol 25(1):88-93

20. Hill RD, Castillo LG, Ngu LQ, Pepion K (1999) Mentoring ethnic minority students for careers in academia: the WICHE Doctoral Scholars Program. Couns Psychol 27(6):827-845

21. Campos CMT, Phinney JS, Perez-Brena N, Kim C, Ornelas B, Nemanim L, Kallemeyn DMP, Mihecoby A, Ramirez C (2009) A mentor-based targeted intervention for high-risk Latino college freshmen: a pilot study Journal of Hispanic Higher Education 8 $(2: 158-178$

22. Neill J. Youth at Risk Version of the Life Effectiveness Questionnaire: The Measurement Scales \& Items. 2007; www.wilderdom.com/tools/ leq/YourhSwcwlopmwnr4LEQSalesPaperItems.htm 